\title{
MODEL PEMBELAJARAN FASILITATIF UNTUK PENINGKATAN KREATIVITAS BELAJAR PROGRAM PENDIDIKAN KESETARAAN PAKET C
}

\author{
Hardika* \\ Sutaryat Trisnamansyah**
}

\begin{abstract}
This research intends to develop a facilitating instructional model which can improve learning creativity in accordance with the characteristics of learning participants, learning group and principles of learning of Package $C$ equivalency education program. The development model was applied to two learning groups of Package $C$ equivalency education program in the City and the District of Malang with a quasi experimental design. It can be concluded that a facilitating instructional model can effectively improve learners' learning creativity on Package $C$ equivalency education program.
\end{abstract}

Keywords: facilitating instructional model, learning, creativity.

\begin{abstract}
Abstrak
Penelitian ini bertujuan untuk mengembangkan model pembelajaran fasilitatif yang dapat meningkatkan kreativitas pembelajaran sesuai dengan karakteristik peserta belajar, kelompok belajar dan prinsipprinsip pembelajaran program pendidikan kesetaraan Paket C. Penelitian dan model pengembangan telah diterapkan di dua kelompok belajar program pendidikan kesetaraan Paket C di Kota dan Kabupaten Malang dengan disain eksperimen kuasi. Dapat disimpulkan bahwa model pembelajaran fasilitatif dapat dengan efektif meningkatkan kreativitas belajar peserta didik pada program pendidikan kesetaraan Paket $C$.
\end{abstract}

Kata kunci: model pembelajaran fasilitatif, belajar, kreativitas.

\section{PENDAHULUAN}

Pembelajaran bukan sekedar transfer pengetahuan (transfer of knowledge), tetapi juga merupakan transfer belajar (transfer of learning) yang harus menghasilkan transformasi pola pikir dan pola tindak (Novak \& Gowin, 2004; Sullivan, 2001). Dalam perspektif psikologi kognitif, belajar bukan sekedar proses penerimaan informasi secara pasif oleh warga belajar, tetapi merupakan proses berpikir secara aktif untuk melakukan pemaknaan seluruh pengalaman belajar. Belajar juga bukan sekedar pemenuhan kebutuhan intelektual dengan keterpaksaan, tetapi merupakan interaksi yang dilandasi kerelaan untuk terlibat dan dilibatkan secara aktif dalam proses pembelajaran (Knowless, 1988; Harefa, 2005). Keterlibatan warga belajar dalam pembelajaran diarahkan pada terbentuknya kepercayaan diri terhadap potensi dan kemampuan warga belajar. Menurut

\footnotetext{
* Dosen Jurusan Pendidikan Luar Sekolah FIP UNM
}

* Dosen Jurusan Pendidikan Luar Sekolah FIP UPI
Abdulhak (2007: 523), pembelajaran harus mampu mempersiapkan warga belajar untuk menampilkan tingkah laku hasil belajar dalam kondisi nyata.

Demikian halnya, pada program pendidikan kesetaraan Paket $\mathrm{C}$, belajar bukan sekedar untuk mencapai angka-angka kelulusan, tetapi harus mampu menciptakan kemandirian dan kreativitas belajar serta kebermanfaatan dalam kehidupannya. Kapasitas intelektual (intellectual capacity) yang dibangun dalam sistem pembelajaran harus diarahkan pada peningkatan kapasitas warga belajar dalam mengelola diri dan lingkungannya. Warga belajar harus didorong untuk memiliki keberanian dalam melakukan improvisasi dan konstruksi interaksi pembelajaran yang lebih dinamis, baik di dalam maupun di luar kelas. Hal ini perlu dilakukan, sebab gaya dan strategi belajar dari masingmasing warga belajar berbeda-beda sesuai dengan karakteristik individu dan sosial yang ada di lingkungannya (Pask, 1977). 
Kreativitas belajar yang dimiliki warga belajar bukan dianggap hal penting oleh sebagian pendidik termasuk pendidikan luar sekolah. Bahkan, sebagian besar pendidik di Indonesia masih menyukai warga belajar yang memiliki tingkat IQ tinggi daripada kreativitas atau kecerdasan lainnya (Munandar, 1999). Dengan pemahaman semacam ini hampir dapat dipastikan, bahwa pola pembelajaran yang berlangsung selama ini belum akan mampu menunjukkan proses dan hasil belajar yang kreatif dengan disertai ide-ide cerdas, baik dari peserta didik maupun pendidiknya.

Demikian halnya, kreativitas belajar dalam pendidikan kesetaraan masih belum terbangun dengan baik. Dalam berbagai kasus pendidikan kesetaraan Paket $C$ ditemukan, bahwa proses pembelajaran belum menghasilkan perubahan sikap, perilaku, dan wawasan belajar sesuai dengan filosofi belajar dalam pendidikan kesetaraan. Tutor belum mampu menempatkan dirinya sebagai fasilitator belajar yang berperan sebagai pendamping, pembantu, pendorong, dan mitra belajar yang menyenangkan (Pujianik, 2005). Dalam situasi seperti itu, warga belajar kurang memiliki kemampuan dan kemauan menelaah bahan ajar, sehingga dalam menyikapi pembelajaran hanya dianggap sebagai pemenuhan kewajiban belaka tanpa disertai pemahaman dan pemikiran yang kritis. Keikutsertaan masyarakat dalam pendidikan kesetaraan $P$ aket $C$ lebih didasarkan pada keinginan yang kuat untuk mendapatkan ijazah tanpa diikuti oleh semangat dan kesungguhan belajar.

Indikator ini tampak jelas ketika warga belajar malas menghadiri kegiatan belajar, sering meninggalkan kelas ketika pembelajaran sedang berlangsung dan tidak memiliki kesungguhan dalam mengerjakan tugas belajar, baik tugas terstruktur maupun mandiri. Warga belajar cenderung pasif hanya menunggu dan mendengarkan cerita serta informasi dari tutor tanpa melakukan respon balik. Aktivitas warga belajar dalam pembelajaran cenderung hanya disikapi sebagai upaya menjalankan perintah tutor dan bukan inisiatif untuk melakukan perubahan dan peningkatan kapasitas diri secara mandiri (Khomariah \& Zulkarnain, 2005). Bahkan di beberapa kelompok belajar Paket $\mathrm{C}$, kehadiran warga belajar dalam proses pembelajaran terlihat sangat rendah dan akan penuh lagi ketika menjelang ujian dilaksanakan (Supriyono dan Hardika 2007).

Menurut Munandar (1999) dan Makiguchi (2002), kreativitas dapat dibangun melalui sistem pembelajaran yang konstruktif dalam suasana saling menghargai terhadap perilaku dan prestasi masing-masing peserta belajar. Dalam upaya penciptaan kreativitas belajar, halhal yang berkenaan dengan potensi warga belajar harus dieksplorasi dan dikembangkan melalui aktivitas pembelajaran. Minat dan keberbakatan warga belajar dideteksi dan ditumbuhkembangkan melalui model pembelajaran yang memiliki relevansi dengan upaya penciptaan kreatvitas belajar.

Makiguchi (2002:23) mengungkapkan bahwa untuk membangun kreativitas peserta belajar, penyelenggara pendidikan harus melakukan refleksi total terhadap hakikat tujuan pendidikan (reflection on purpose of education), dasar-dasar nilai pendidikan (fundamentals of education value), melakukan revitalisasi pendidikan (revitalization of education), dan memahami berbagai bahan pembelajaran dan metodologi kependidikan (educational methodology and teaching material) terkini. Dalam konteks ini, kreativitas belajar warga belajar dapat dikembangkan melalui proses eksplorasi dan konstruksi ulang model pembelajaran yang berakar pada karakter dan potensi warga belajar. Model pembelajaran harus dibangun atas dasar refleksi tujuan pendidikan dan hakikat nilai-nilai pendidikan, metodologi pembelajaran yang tepat, perangkat dan material pembelajaran yang sesuai dengan misi pembelajaran serta mampu membangkitkan minat dan semangat belajar yang tinggi.

Di samping itu, karakter tutor sebagai fasilitator belum tampak dalam proses interaksi pembelajaran, tutor cenderung melakukan intervensi vertikal tentang pola belajar kepada warga belajar, sehingga kreativitas belajar tidak berkembang. Tutor belum memiliki kemauan dan kemampuan yang memadai dalam perancangan dan implementasi model pembelajaran berbasis warga belajar sesuai dengan karakteristik sosial dan pribadi warga belajar serta filosofi pendidikan luar sekolah. Model fasilitasi pembelajaran dalam terminologi pendidikan luar sekolah, khususnya pendidikan kesetaraan masih merupakan model yang "mahal", sehingga proses implementasinya pun belum berjalan dengan baik. Hal ini dikarenakan sebagian besar pendidik luar sekolah masih beranggapan bahwa pemilihan model pembelajaran merupakan otoritas mutlak pendidik, sehingga pemilihan strategi belajar cenderung bersifat sentralistis oleh tutor tanpa melibatkan potensi warga belajar.

Berbekal kedewasaan dan pengalaman yang banyak, warga belajar Paket $C$ tentu telah memiliki tanggung jawab dan kemampuan belajar (responsibility and ability to learn) untuk melakukan kegiatan belajar secara bertanggung jawab dan profesional (Kamil, 2007). Pengembangan model pembelajaran yang mampu meningkatkan pemahaman dan kemampuan tutor dalam menciptakan kreativitas belajar memiliki relevansi dan urgensi dalam peningkatan kualitas 
pembelajaran. Kualitas pembelajaran yang baik harus mengutamakan prinsip transformatif dalam setiap interaksi pembelajaran (King, 2005). Pengembangan model pembelajaran fasilitatif ini dibangun berdasar atas pendapat Havelock (2000) dan Swarchz (2002) yang menekankan pada peran fasilitasi dalam pembelajaran. Perumusan Masalah

Dalam praktik pembelajaran program pendidikan kesetaraan Paket $C$ dapat diidentifikasi beberapa masalah, yaitu tutor belum memberikan pencerahan kepada warga belajar tentang hakikat dan filosofi pembelajaran pendidikan kesetaraan Paket $C$, proses dan strategi pembelajaran, peran tutor dan warga belajar dalam interaksi pembelajaran, dan dampak belajar bagi kehidupan warga belajar. Tutor juga belum menggunakan model pembelajaran yang benar-benar relevan dengan karakteristik dan filosofi pembelajaran pendidikan kesetaraan Paket $C$ yang lebih mengutamakan prinsip kemandirian dan kreativitas belajar.
Berkenaan dengan hal tersebut, maka rumusan masalah yang akan dipecahkan dalam penelitian ini adalah sebagai berikut "Bagaimana model fasilitasi pembelajaran yang efektif dapat mengembangkan kreativitas belajar warga belajar dalam program pendidikan kesetaraan Paket C?"

\section{Tujuan Penelitian}

Atas dasar argumentasi tersebut di atas, penelitian ini bertujuan untuk mengembangkan model pembelajaran fasilitatif yang mampu meningkatkan kreativitas belajar warga belajar program pendidikan kesetaraan Paket C. Pengembangan model pembelajaran fasilitatif dalam penelitian ini dimulai dari pemaparan tentang kondisi empirik pembelajaran Paket C, konstruksi model fasilitasi pembelajaran, proses implementasi model fasilitasi pembelajaran, dan efektivitas model fasilitasi pembelajaran dalam peningkatan kreativitas belajar program pendidikan kesetaraan Paket C.

\section{KAJIAN TEORETIS}

\section{Kreativitas Belajar}

Kreativitas belajar merupakan salah satu produk belajar yang dapat dicapai melalui rancangan pembelajaran yang berorientasi pada proses dan berakar pada masalah yang dihadapi warga belajar (problem posing model). Model ini dilakukan dengan cara mendorong terjadinya partisipasi aktif warga belajar, mengangkat pengalaman warga belajar untuk diuji menjadi bahan belajar/bahan dialog pembelajaran, suasana pembelajaran dirancang penuh kerjasama dengan pelibatan aktif warga belajar, dan evaluasi dilakukan bersama antara tutor dan warga belajar melalui uji reflektif dan berpikir kritis.

Substansi model pembelajaran fasilitatif ini meliputi pengembangan peran tutor sebagai fasilitator belajar, penguatan peran warga belajar sebagai subjek belajar (pelaku dan sasaran utama dalam pembelajaran), pendayagunaan seluruh potensi lingkungan dan pengalaman warga belajar sebagai sumber pembelajaran, penerapan kata-kata persuasif untuk pembangkitan semangat belajar, penggunaan teknik ice breaking untuk mengurangi ketegangan belajar, penciptaan kreativitas belajar sebagai produk belajar, dan penerapan evaluasi reflektif untuk peningkatan berpikir kritis (critical thinking).

Oleh karena produk penelitian tentang kreativitas belajar ini berupa performansi warga belajar dalam proses belajar (learning performance), maka pelibatan dan keterlibatan warga belajar harus sudah dibangun sejak persiapan pembelajaran. Pelibatan dan keterlibatan warga belajar dilakukan dengan cara mengajak warga belajar untuk merekonstruksi hakikat belajar dan pembelajaran, melakukan kontrak belajar, mendiskusikan model pembelajaran yang akan diterapkan, membangkitkan kembali semangat belajar melalui katakata persuasif dan ice breaking, pemberian beban belajar secara konsisten dan konstruktif, dan evaluasi belajar melalui evaluasi diri (self evaluation), refleksi kritis (critical reflective/critical thinking), dan penentuan kesadaran atas dirinya sendiri (self determination and self awareness).

\section{METODOLOGI PENELITIAN}

Penelitian ini menggunakan pendekatan deskriptif kualitatif dan kuantitatif dengan rancangan penelitian dan pengembangan pendidikan (educational research and development) versi Borg dan Gall (2003). Tujuan akhir yang ingin dicapai dalam penelitian ini adalah lahirnya produk baru tentang model pembelajaran fasilitatif yang mampu meningkatkan kreativitas belajar warga belajar pada program pendidikan kesetaraan Paket C. Proses penelitian diawali dengan kajian pendahuluan (preliminary research) yang 
dilakukan di beberapa Kelompok Belajar Paket C di Kota dan Kabupaten Malang serta didukung oleh beberapa hasil penelitian dari beberapa kelompok belajar Paket $\mathrm{C}$ di Jawa Timur. Pengumpulan data dilakukan dengan menggunakan angket, wawancara, observasi, studi dokumentasi, dan lembar catatan lapangan tentang performansi warga belajar dalam proses pembelajaran.

Untuk keperluan uji efektivitas model dipilih dua kelompok belajar Paket $\mathrm{C}$ di Kota dan Kabupaten Malang sebagai kelompok eksperimen dan kelompok kontrol. Penelitian dilakukan dengan menggunakan model kuasi eksperimen melalui "desain dengan kelompok pembanding tanpa pretest" terhadap dua sampel independen (nonequivalent group post test only design). Penggunaan desain ini didasari oleh pendapat Sprinthall, dkk (1991:68-69) dan Wiersma (1991) yang mengatakan bahwa nonequivalent group post test only design dapat dilakukan terhadap kelompok eksperimen maupun kelompok kontrol (pembanding) tanpa melakukan pretest jika data awal tentang variabel yang akan diteliti telah diketahui.

Berdasarkan argumentasi tersebut, maka desain penelitian ini dapat digambarkan sebagai berikut:

\begin{tabular}{llr|}
\hline $\boldsymbol{G}_{\mathbf{1}}$ & $\mathbf{X}$ & $\boldsymbol{O}_{\mathbf{1}}$ \\
$\boldsymbol{G}_{\mathbf{2}}$ & - & $\boldsymbol{O}_{\mathbf{2}}$ \\
\hline$G_{1}=$ & kelompok eksperimen (experimental group) \\
$G_{2}$ & $=$ kelompok & kontrol/pembanding (control \\
& group) \\
$\mathrm{X}=$ & perlakuan (experimental treatment) \\
$O_{1}=$ & pengukuran atau posttest untuk kelompok \\
& eksperimen \\
$O_{2}=$ & pengukuran atau posttest untuk kelompok \\
& kontrol/pembanding
\end{tabular}

\section{Gambar 1. Desain Penelitian}

Dipilihnya desain ini didasari argumentasi bahwa kreativitas belajar warga belajar telah diketahui secara mendalam melalui proses preliminary research yang secara konsisten menunjukkan kreativitas belajar warga belajar Paket $C$ belum berkembang maksimal. Atas dasar fakta tersebut, maka peneliti tidak melakukan pretest untuk mengetahui keadaan awal kreativitas belajar warga belajar. Namun demikian, model post test yang dilakukan dalam penelitian ini bukan berarti menggambarkan kemampuan akhir warga belajar tentang kreativitas belajarnya, tetapi lebih menunjukkan aspek waktu diselenggarakannya tes tentang kreativitas belajar dalam rentang waktu proses pembelajaran.

Adapun langkah-langkah pelaksanaan kuasi eksperimen dalam penelitian ini meliputi (1) penentuan kelompok eksperimen dan kelompok pembanding secara random, (2) melakukan persiapan lapangan terutama kesiapan kelompok eksperimen dan kelompok pembanding, (3) melaksanakan experimental treatment melalui proses pembelajaran, (4) melakukan perekaman data melalui observasi, wawancara, studi dokumentasi dan angket, (5) melaksanakan analisis data untuk mengetahui peningkatan kreativitas belajar warga belajar, baik pada kelompok eksperimen maupun pembanding, dan (6) melakukan analisis kuantitatif dengan menggunakan uji t untuk mengetahui perbedaan rerata skor kreativitas kelompok eksperimen dan pembanding.

Adapun konstruksi model pembelajaran fasilitatif yang dikembangkan dalam penelitian ini dapat digambarkan sebagai berikut:

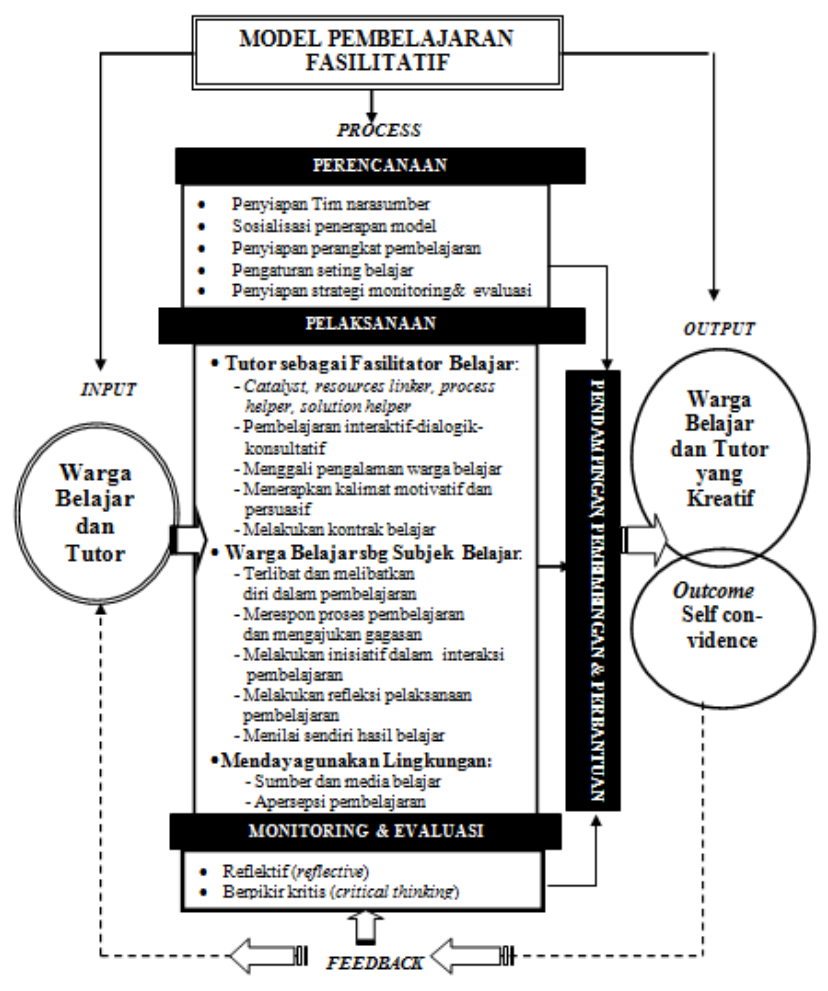

Gambar 2. Konstruksi Model Pembelajaran Fasilitatif

\section{HASIL PENELITIAN}

Model pembelajaran yang selama ini diterapkan pada program pendidikan kesetaraan Paket $C$ belum mampu menciptakan kreativitas belajar warga belajar, sehingga warga belajar sangat bergantung pada eksistensi dan kehadiran tutor di dalam kelas. Oleh karena ketergantungan warga belajar terhadap 
kehadiran dan eksistensi tutor sangat tinggi, maka posisi tutor sangat sentral dan dominan dalam proses pembelajaran. Tutor dianggap sebagai satu-satunya sumber informasi serba bisa yang menguasai segala persoalan pembelajaran dan berperan sebagai transmitter ilmu pengetahuan kepada warga belajar. $\mathrm{Hal}$ ini bertentangan dengan semangat dan filosofi pembelajaran kesetaraan Paket $C$ yang sebenarnya lebih mengutamakan proses belajar mandiri dengan model fasilitasi dan tutorial.

Model pembelajaran fasilitatif pada program pendidikan kesetaraan Paket $C$ yang dikembangkan dalam penelitian ini secara empirik mampu meningkatkan kreativitas belajar warga belajar, baik pada tahap perencanaan, pelaksanaan, maupun evaluasi pembelajaran. Hasil hitungan statistik diketahui, bahwa rerata skor kreativitas ( ) kelompok eksperimen dengan $\mathrm{N}=54$ adalah 72,148 dan rerata skor kreativitas $\left(\bar{X}_{2}\right)$ kelompok kontrol/pembanding untuk $\mathrm{N}=51$ adalah 58,000 . Adapun varian kelompok eksperimen $\left(S_{1}{ }^{2}\right)$ sebesar 100,430 dan varian kelompok kontrol $\left(S_{2}^{2}\right)$ sebesar 112,320. Harga derajat kebebasan (db) untuk dua sampel independent dalam penelitian ini $54+53-$ $2=103$ yang dihitung berdasarkan rumus $n_{1}+n_{2}-2$ (Popham dan Sirotnik, 1973:141). Melalui analisis statistik uji t diketahui $t_{\text {empirik }}$ dalam penelitian ini adalah 7,021 , sedangkan harga $t_{\text {tabel }}$ untuk tingkat signifikansi $95 \%$ dengan db 103 adalah 1,980. Oleh karena hasil hitungan harga $t_{\text {empirik }} 7,021>t_{\text {tabel }} 1,980$, maka hipotesis nol dalam penelitian ini tidak diterima (ditolak) karena tidak didukung oleh data. Hasil uji eksperimen membuktikan bahwa kreativitas belajar warga belajar Paket $C$ yang menggunakan model pembelajaran fasilitatif berbeda lebih tinggi dibanding kreativitas warga belajar Paket $C$ yang tidak menggunakan model pembelajaran fasilitatif. Model pembelajaran fasilitatif terbukti lebih atraktif, sehingga mampu meningkatkan tantangan dan dinamika belajar yang pada akhirnya mampu menghasilkan kreativitas belajar pada diri warga belajar.

Ada beberapa temuan penting yang harus dikuasai tutor dalam kaitannya dengan pembelajaran fasilitatif, yaitu (1) filosofi pembelajaran pendidikan kesetaran Paket $C$ sebagai proses penciptaan kemandirian belajar, (2) hakikat tujuan pembelajaran masyarakat sebagai proses pemberdayaan, (3) teknik komunikasi sosial untuk meningkatkan keakraban antar warga belajar dan tutor, (4) sistem organisasi pembelajaran orang dewasa sebagai landasan pembelajaran, (5) teknik dan metode pembelajaran sesuai dengan karakteristik warga belajar, (6) ketersediaan sumber-sumber belajar yang relevan dengan kebutuhan warga belajar, (7) peran dan posisi tutor sebagai partner belajar, dan (8) identifikasi kebutuhan dan sumber belajar warga belajar untuk merumuskan bahan dan media belajar. Berkenaan dengan hal tersebut, diperlukan pelatihan tutor untuk meningkatkan dan memperbaharui pemahamannya tentang model dan implementasi pembelajaran fasilitatif.

Pendidikan kesetaraan Paket $\mathrm{C}$ merupakan pendidikan alternatif bagi warga masyarakat yang tidak berkesempatan mengikuti pendidikan formal pada jenjang SMA/MA atau yang sederajat. Ditinjau dari sisi rentang waktu pelaksanaan belajar, pendidikan kesetaraan ini dirancang sebagai program pembelajaran yang lebih mengutamakan belajar mandiri dengan penuh kreativitas dan daya inisiatif warga belajar. Hal ini dapat dipahami, sebab jumlah jam belajar yang lebih sedikit dan rentang belajar yang pendek dibanding pendidikan formal, maka kemandirian belajar dengan sistem tutorial merupakan model pembelajaran yang harus dipahami dan diterima oleh warga belajar.

Berbagai pemahaman dan kelemahan yang ada pada pendidikan kesetaraan tersebut telah menciptakan stigma masyarakat, bahwa pendidikan kesetaraan adalah jenis pendidikan yang tidak bergengsi dan hanya bersifat sementara untuk menampung siswa SMA yang tidak lulus serta masyarakat yang lemah kemampuan akademiknya. Berkenaan dengan berbagai persoalan tersebut, muncul beberapa sikap sinis dan kurang respek terhadap pendidikan kesetaraan, sehingga sempat ada pemikiran untuk membubarkan pendidikan kesetaraan karena dianggap tidak qualified (Mudzakir, 2009).

Berkaitan dengan persoalan di atas, dalam proses pembelajaran pendidikan kesetaraan peran tutor sebagai fasilitator sangat diperlukan mengingat karakteristik warga belajar relatif sudah dewasa dengan berbagai pengalaman hidup, pengalaman kerja dan pengalaman belajar. Optimalisasi peran tutor sebagai fasilitator harus dikembangkan berdasar pada karakter warga belajar, situasi dan kondisi warga belajar, dan potensi lingkungan dan pengalaman belajar warga belajar. Berkaitan dengan prinsip-prinsip pembelajaran fasilitatif, maka ciri-ciri peran tutor dalam pembelajaran adalah (1) tutor selalu merespon perasaan warga belajar, (2) memanfaatkan ide dan pengalaman warga belajar untuk merumuskan model pembelajaran, (3) melakukan dialog dan diskusi dengan warga belajar, (4) menghargai warga belajar sebagai manusia yang bermartabat, (5) bersikap familiar dan terbuka kepada warga belajar, (6) merumuskan model pembelajaran sesuai dengan karakteristik warga belajar dan 
lingkungan belajar, (7) bersikap empati, respek dan peka terhadap kehendak serta perasaan warga belajar (Gross, 2004).

Model pembelajaran fasilitatif memiliki kelenturan dan fisibilitas untuk diterapkan dalam pembelajaran berkarakter pendidikan nonformal. Akan tetapi implementasi model ini juga dipengaruhi oleh kemampuan dan kemauan tutor dalam memerankan dirinya sebagai fasilitator belajar, kemampuan dalam menerapkan kata-kata persuasif, kemampuan menciptakan suasana segar dalam pembelajaran (ice breaking), peran warga belajar sebagai subjek belajar, dan kekuatan tutor dalam mengembangkan interaksi pembelajaran. Berkenaan dengan hal tersebut, implementasi peran tutor sebagai fasilitator belajar yang di dalamnya meliputi catalyst, resources linker, process helper, dan solution helper harus diterapkan secara fleksibel sesuai dengan situasi dan kebutuhan warga belajar. Penerapan fasilitasi pembelajaran harus memperhatikan filosofi "belajar bagaimana cara belajar" (learning how to learn), dengan prinsip belajar melalui pendampingan (learning by facilitating), belajar berkelompok (learning together), belajar sambil dialog (learning by dialoque), belajar dengan kepercayaan diri (learning by self reliance), belajar melalui lingkungan sosial (learning by social environmental) dan belajar mengembangkan jati diri (learning to be self).

Oleh karena produk penelitian tentang kreativitas belajar ini berupa performansi warga belajar dalam proses belajar (learning performance), maka pelibatan dan keterlibatan warga belajar harus sudah dibangun sejak persiapan pembelajaran. Pelibatan dan keterlibatan warga belajar dilakukan dengan cara mengajak warga belajar untuk merekonstruksi hakikat belajar dan pembelajaran, melakukan kontrak belajar, mendiskusikan model pembelajaran yang akan diterapkan, membangkitkan kembali semangat belajar melalui kata-kata persuasif dan ice breaking, pemberian beban belajar secara konsisten dan konstruktif, dan evaluasi belajar melalui evaluasi diri (self evaluation), refleksi kritis (critical reflective/critical thinking), dan penentuan kesadaran atas dirinya sendiri (self determination and self awareness).

Memperhatikan hasil penelitian yang berhasil disimpulkan di depan, ada tiga persoalan yang perlu diperhatikan dalam pengembangan pembelajaran fasilitatif dalam pendidikan kesetaraan, yaitu (1) penghargaan prestasi dan kelulusan warga belajar harus dihimpun dari aspek prestasi kenerja dalam melakukan belajar, (2) kualitas dan kelayakan hasil tugas mandiri atau portopolio yang dicapai warga belajar selama pembelajaran, (3) peningkatan kapasitas dan kapabilitas tutor dalam memahami karakter warga belajar dan misi pendidikan kesetaraan, (4) pemanfaatan sarana dan medan belajar yang menyenangkan dan bervariasi. Beberapa hal tersebut di atas, secara empirik memiliki kontribusi dalam perubahan sikap dan perilaku warga belajar untuk lebih aktif, atraktif dan kreatif dalam menjalani pembelajaran.

Menurut Schwarz (2002), pembelajaran fasilitatif memiliki kekuatan dalam menggerakkan dinamika kelompok untuk mencapai tujuan yang diinginkan. Fasilitator berkewajiban membantu meningkatkan efektivitas kegiatan melalui komitmen anggota kelompok yang bersangkutan. Komitmen anggota kelompok merupakan salah satu kunci atau inti dari keberhasilan pembelajaran fasilitatif. The facilitator's main task is to help the group increace effectiveness by improving its process and structure ...the core values of facilitation state that a group is more effective if the group is internally committed to its choice (Schwarz, 2002:23).

Berkenaan dengan efektivitas pembelajaran fasilitatif dalam kelompok belajar Paket $C$, kesepakatan kelompok yang telah dirumuskan bersama, harus menjadi komitmen bersama melalui peningkatan dan pemberdayaan kelompok belajar. Kelompok belajar merupakan medan dan wadah belajar yang dianggap paling relevan dalam pembelajaran pendidikan luar sekolah yang berbasis fasilitatif. Proses kelompok bukan berarti meninggalkan intensitas dan kapasitas individu warga belajar, tetapi proses belajar dibangun atas dasar saling membelajarkan dan saling menghargai sesama warga belajar dalam sistem kelompok. Menurut Hackman, dalam (Schwarz, 2002), ada tiga faktor yang berkontribusi dalam peningkatan efektivitas kelompok, yaitu proses kelompok (group process), struktur kelompok (group structure) dan konteks kelompok (group context). Kelompok harus mampu bergerak dan bekerja dengan baik, memiliki struktur tatanan dan pengelolaan yang benar, dan memiliki relevansi atau memperhatikan konteks dan tujuan kelompok yang bersangkutan.

Berikut disajikan salah satu model pemecahan masalah pembelajaran berbasis fasilitasi.

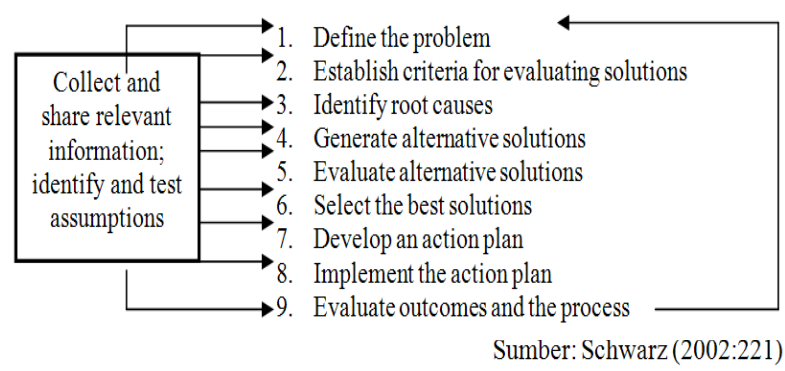

Gambar 3. Model Pemecahan Masalah Pembelajaran Berbasis Fasilitasi 
Efektivitas kelompok belajar pendidikan kesetaraan Paket $C$ dalam pencapaian hasil belajar harus dibangun dengan mendinamisasikan dan menggerakkan sistem belajar melalui pengelolaan yang lebih baik, kepengurusan belajar yang profesional, yaitu kepengurusan yang memiliki kapasitas dan kapabilitas dalam pemberdayaan warga belajar. Terkait pembelajaran fasilitatif, proses, struktur dan konteks kelompok harus didasarkan pada peningkatan kapasitas dan profesionalitas serta ketersediaan tutor, kelengkapan organ kepengurusan kelompok belajar, ketersediaan narasumber teknis, dan profesionalitas kerja tim administrasi. Dalam kaitan pembelajaran model fasilitatif, perlu juga mulai dipikirkan tim peneliti dan pengembang (litbang) yang bertugas untuk mengkaji berbagai perkembangan dan issue tentang model pembelajaran pendidikan kesetaraan.

Pengembangan kretivitas belajar melalui pembelajaran fasilitatif memiliki keterkaitan yang kuat dengan upaya perubahn sikap belajar. Pembahasan tentang sikap belajar kreatif dalam kaitannya dengan implementasi model pembelajaran fasilitatif, tentu akan banyak melibatkan faktor yang mempengaruhi terjadinya perubahan dan pembentukan sikap seseorang terhadap objek belajar. Relevansi, kemenarikan objek belajar dan model pembelajaran yang dalam hal ini adalah model pembelajaran fasilitatif akan menjadi fokus penting dalam peningkatan kreativitas belajar. Fasilitator belajar berada dalam titik sentral dalam pengendalian proses belajar. Keterbukaan, keterlibatan dan motivasi fasilitator dalam mengembangkan berpikir kritis warga belajar merupakan faktor penting dalam proses fasilitasi pembelajaran.

Pambentukan dan perubahan sikap warga belajar tidak terjadi dengan sendirinya, tetapi senantiasa berlangsung dalam interaksi antar manusia dan berkenaan dengan model pembelajaran yang diterapkan. Salah satu faktor yang mempengaruhi terjadinya perubahan sikap warga belajar adalah adanya pengaruh atau respon dari luar yang mampu mempengaruhi sikap yang telah lebih dahulu bercokol dalam diri seseorang. Namun demikian, bagaimanapun besarnya pengaruh dari luar, apabila faktor internal warga belajar belum mau menerimanya, maka tidak akan menghasilkan perubahan sikap baru. Oleh karena itu, model pembelajaran fasilitatif sebagai objek sikap, tentu akan direspon oleh warga belajarnya jika memiliki kemenarikan, relevansi, dorongan eksternal dan internal warga belajar.

Kreativitas bukan murni perilaku bawaan atau bakat, tetapi merupakan hasil dari proses pendidikan yang melibatkan potensi lingkungan secara optimal, kekuatan pendidik dalam mengubah potensi lingkungan sebagai modal belajar, dan rekayasa karakter peserta didik sebagai subjek belajar. Dengan kata lain, kreativitas akan muncul ke permukaan setelah melalui proses rekayasa sosial (social enginering) dengan melibatkan seluruh unsur lingkungan yang terkait dengan subjek belajar dan sistem pembelajaran. Rekayasa sosial yang dimaksud dalam pembahasan ini adalah terciptanya suasana kebudayaan creativogeneic. Creativogoneic menurut Silvano Arieti, dalam (Munandar, 1999:176) adalah suatu kebudayaan yang menunjang, memupuk dan memungkinkan berkembangnya kreativitas seseorantg dalam sistem kehidupannya.

Dibanding dengan substansi pembelajaran yang lain, kreativitas masih tergolong baru sebagai bidang aktivitas akademik yang bersistem dan menjadi kajian riset yang bersifat empiris. Kajian terhadap kreativitas baru diungkap secara empiris dalam kontek pembelajaran setelah terjadi Perang Dunia kedua melalui pidato bersejarah Guilford tahun 1950 sebagai Presiden American Psychological Association (APA), yang menekankan "the appalling neglect" tentang pentingnya studi kreativitas dan mengingatkan akan kebutuhan kreativitas di masyarakat melalui berbagai sistem pembelajaran dan pendidikan. Di samping itu, peluncuran Sputnik tahun 1957 dianggap sebagai ancaman bagi Amerika untuk mempertahankan keunggulannya di bidang teknologi, yang akhirnya mendorong Amerika mengobarkan pendidikan yang berbasis pada pengembangan kreativitas peserta didik. Kedua peristiwa tersebut dianggap oleh kalangan pendidik sebagai cikal bakal lahirnya demensi kreativitas sebagai kajian empiris dalam berbagai sistem pembelajaran (Munandar, 1999).

Dalam perkembangan selanjutnya, kreativitas telah menjadi fokus kajian penting dalam sistem pendidikan dan menyebar ke berbagai aktivitas manusia baik dalam sistem pembelajaran maupun dunia kerja yang lain. Bahkan, kreativitas merupakan bagian integral yang tidak terpisahkan dari sistem kecerdasan seseorang selain kecerdasan intelektual, emosional, sosial, dan spiritual. Prinsip dasar kreativitas dapat dilacak dari kemampuan berpikir konvergen dan berpikir divergen. Pemikiran konvergen dengan suatu penalaran yang logis dan mengarah pada jawaban 'benar' merupakan proses yang mendasari pengukuran kecerdasan tradisional, sedangkan pemikiran divergen adalah corak pemikiran yang menghasilkan bermacammacam gagasan dan ini merupakan indikator paling nyata dari kreativitas. 
Salah satu masalah yang kritis dalam pengembangan kreativitas adalah masalah kriteria. Pada umumnya para ahli sepakat, bahwa tidak mudah merumuskan kriteria yang tepat dalam menemukan dan mengembangkan kreativitas. Makiguchi (1989) mengingatkan, bahwa tidak mungkin menemukan kriteria kreativitas yang tidak bercampur dengan ciriciri dan perilaku manusia lainnya, terutama intelegensi, sebab kreativitas merupakan konstruk yang multi demensional. Apalagi hasil riset yang telah dilakukan membuktikan, bahwa sebagian besar guru masih menyenangi anak yang memiliki IQ tinggi dibanding dengan anak yang memiliki dasar kreativitas bagus.
Padahal, kenyataan empirik menunjukkan bahwa kreativitas memiliki kelebihan dalam banyak hal termasuk kemampuannya dalam menyelesaikan masalah dengan baik sebagaimana masalah yang diselesaikan oleh mereka yang memiliki IQ tinggi (Munandar, 1999). Untuk menciptakan suasana yang mendukung terciptanya kreativitas belajar, fasilitator belajar harus mampu menempatkan dirinya sebagai pendamping belajar yang baik, dengan berperan sebagai catalyst, process helper, resources linker, dan solution helper. Dengan cara ini tutor bukan sekedar melaksanakan transfer of knowledge kepada peserta didik, tetapi lebih ditekankan pada transfer of process.

\section{KESIMPULAN}

\section{Kesimpulan}

Model pembelajaran fasilitatif dalam program pendidikan kesetaraan Paket $C$ yang dikembangkan dalam penelitian ini mampu meningkatkan kreativitas belajar warga belajar, baik pada tahap perencanaan, pelaksanaan maupun evaluasi pembelajaran. Hasil ujieksperimen membuktikan, bahwa kreativitas belajar warga belajar program pendidikan kesetaraan Paket C yang menggunakan model pembelajaran fasilitatif berbeda lebih tinggi dibanding kreativitas warga belajar Paket $C$ yang tidak menggunakan model pembelajaran fasilitatif. Dengan kreativitas belajar yang dimiliki warga belajar, maka proses pembelajaran belangsung lebih dinamis, atraktif, menantang, dan menyenangkan.

Substansi model pembelajaran fasilitatif ini meliputi pengembangan peran tutor sebagai fasilitator belajar, penguatan peran warga belajar sebagai subjek belajar (pelaku dan sasaran utama dalam pembelajaran), pendayagunaan seluruh potensi lingkungan dan pengalaman warga belajar sebagai sumber pembelajaran, penerapan kata-kata persuasif untuk pembangkitan semangat belajar, penggunaan teknik ice breaking untuk mengurangai ketegangan belajar, penciptaan kreativitas belajar sebagai produk belajar, penerapan evaluasi reflektif untuk peningkatan berpikir kritis (critical thingking).

Berkenaan dengan kesimpulan hasil penelitian ini, ada beberapa hal yang harus dikuasai tutor sebagai fasilitator belajar, yaitu (1) proses penciptaan kemandirian belajar, (2) pemberdayaan warga belajar dalam aktivitas pembelajaran, (3) teknik komunikasi sosial, (4) sistem organisasi pembelajaran orang dewasa, (5) karakteristik warga belajar orang dewasa, (6) ketersediaan sumber-sumber belajar yang relevan dengan kebutuhan warga belajar, (7) peran dan posisi tutor sebagai pendamping belajar, dan (8) identifikasi kebutuhan dan sumber belajar warga belajar. Oleh karena itu, untuk memaksimalkan proses fasilitasi pembelajaran terlebih dahulu diperlukan pelatihan tutor untuk meningkatkan, memperbaharui dan mengkonstruksi ulang (reconstruction) pengetahuan tutor tentang model fasilitasi pembelajaran.

\section{Saran}

Berdasarkan pada temuan tersebut, direkomendasikan kepada direktorat pendidikan kesetaraan, pusat pengembangan pendidikan nonformal-informal, pusat kegiatan belajar masyarakat, kelompok belajar Paket $\mathrm{C}$ dan praktisi pembelajaran pendidikan nonformal agar memanfaatkan hasil penelitian ini sebagai inspirasi dan rujukan dalam peningkatan kualitas dan kreativitas belajar warga belajar. Di samping itu direktorat pendidikan kesetaraan bersama-sama dengan pakar dan pemangku kepentingan pendidikan kesetaraan perlu mengkaji ulang dan merumuskan kembali kompetensi warga belajar pendidikan kesetaraan Paket $C$, khususnya yang berkenaan dengan capaian produk belajar dan proses pembelajaran yang memiliki relevansi dengan filosofi pendidikan luar sekolah. Kompetensi warga belajar dalam pendidikan kesetaraan Paket $\mathrm{C}$ perlu diperkuat dengan aspek kreativitas belajar, terutama yang berkaitan dengan capaian kinerja proses dan kemandirian belajar. Kompetensi tutor juga harus mulai dikerucutkan pada kapasitas dan kapabilitas dirinya sebagai fasilitator belajar (change agent on learning) agar proses pembelajaran yang dibangun tutor memiliki kekuatan untuk menghasilkan kapasitas intelektual sesuai dengan profesinya. 


\section{DAFTAR PUSTAKA}

Abdulhak, I. (2007). Teknologi pendidikan dalam ilmu dan aplikasi pendidikan. Bandung: Pedagogiana Press.

Borg, W.R. \& Gall, M.D. (2003). Educational research: An Introduction. Third edition. New York: Longman.

Gross, R. (2004). Peak learning how to create your own lifelong education program for personal enjoyment and profesional success. New York, Jeremy P.Tarcher/Putnam a member of Penguin Putnam Inc.

Harefa, A. (2005). Menjadi manusia pembelajar (On becoming a learner): Pemberdayaan diri, transformasi organisasi dan masyarakat lewat proses pembelajaran. Jakarta: PT Kompas Media Nusantara.

Havelock, RG. (2000). The change agent's guide. Second edition. New Jersey: Educational Technology Publications Englewood Cliffs.

Kamil, M. (2007). Teori andragogi dalam ilmu dan aplikasi pendidikan. Bandung: Pedagogiana Press.

King, K.P. (2005). Bringing transformative learning to life. Malabar, Florida: Krieger Publising Company.

Knowles, M.S. (1988). The adult learner a neglected species. Houston: Gulf Publishing Company.

Makiguchi, T. (1989). Education for creative living. Dalam Bethel, DM (editor). Ames: lowa University Press.

Makiguchi, T. (2002). Education for creative living. Dalam Bethel, DM (editor). Ames: lowa University Press.

Munandar, S.C.U. (1999). Creativity and education: A studi of the relationship between measures of creative thinking and a number of educational variables in Indonesian primary and junior secondary schools. Jakarta: Ditjen Dikti Depdikbud.

Mudzakir, D.M. (2009). Mempertanyakan program paket c dalam komunikasi: Majalah kampus Universitas Negeri Malang. Malang: Universitas Negeri Malang.
Novak, J.D.\& Gowin, B.D. (2004). Learning how to learn. London : Cambridge University Press.

Pask, G. (1977). Styles and strategies of learning. British joernal of educational psychology. Ed. 46.

Popham, W.J.\& Sirotnik, K.A. (1973). Educational statistics: Use and interpretation. Second edition. New York: Harper \& Row Publishers.

Pujianik, (2005). Alasan ketidakaktifan warga belajar pada program paket c: Studi kasus di kecamatan upitu. Tesis Magister. Malang: Universitas Negeri Malang. Tidak diterbitkan.

Riswandi, I. (2009). Generasi teknik fasilitasi dalam experiential learning. Diakses pada tanggal 29 November 2009 dari http://surya554sangtrainer.wordpress.com/2008/07/21/generasiteknik-fasilitasi-dalam-experiential-learning/.

Schwarz, R. (2002). The skilled facilitator: A comprehensive resource for consultants, facilitators, managers, and coaches. San Francisco: Jossey Bass A Willey Company.

Sprinthall, RC, Schumutte, GT, Sirois, L. (1991). Understanding educational research. New Jersey: Prentice Hall Inc.

Sullivan, E .O'. (2001). Transformative learning. Educational vission for the 21st century. Toronto: Published in Association with University of Toronto Press

Supriyono dan Hardika. (2008). Model pengelolaan ketuntasan belajar pada program pendidikan kesetaraan dengan pola satuan kredit kompetensi (SKK) untuk berbagai moda belajar masyarakat. Penelitian Hibah Bersaing DP2M Direkturat Jenderal Dikti Depdiknas. Tidak Diterbitkan

Wiersma, W. (1991). Research methods in education: An introduction. Fifth Edition. Boston: Allyn and Bacon, A Divission of Simon \& Schuster. Inc.

Zulkarnain dan Komariyah, L. (2005). Strategi learning contract secara berkelompok dengan penilaian portofolio untuk meningkatkan keaktifan dan hasil belajar mahasiswa. dalam Mahakam. Jurnal IImiah Lembaga Penelitian Universitas Mulawarman, Edisi IV, No.1, Juni 2005, halaman 28-42. 